\title{
Endurance-Type Exercise Increases Bulk and Individual Mitochondrial Protein Synthesis Rates in Rats
}

Citation for published version (APA):

Holwerda, A. M., Bouwman, F. G., Nabben, M., Wang, P., van Kranenburg, J., Gijsen, A. P., Burniston, J. G., Mariman, E. C. M., \& van Loon, L. J. C. (2020). Endurance-Type Exercise Increases Bulk and Individual Mitochondrial Protein Synthesis Rates in Rats. International Journal of Sport Nutrition and Exercise Metabolism, 30(2), 153-164. https://doi.org/10.1123/ijsnem.2019-0281

Document status and date:

Published: 01/03/2020

DOI:

10.1123/ijsnem.2019-0281

Document Version:

Publisher's PDF, also known as Version of record

\section{Document license:}

Taverne

\section{Please check the document version of this publication:}

- A submitted manuscript is the version of the article upon submission and before peer-review. There can be important differences between the submitted version and the official published version of record.

People interested in the research are advised to contact the author for the final version of the publication, or visit the DOI to the publisher's website.

- The final author version and the galley proof are versions of the publication after peer review.

- The final published version features the final layout of the paper including the volume, issue and page numbers.

Link to publication

\footnotetext{
General rights rights.

- You may freely distribute the URL identifying the publication in the public portal. please follow below link for the End User Agreement:

www.umlib.nl/taverne-license

Take down policy

If you believe that this document breaches copyright please contact us at:

repository@maastrichtuniversity.nl

providing details and we will investigate your claim.
}

Copyright and moral rights for the publications made accessible in the public portal are retained by the authors and/or other copyright owners and it is a condition of accessing publications that users recognise and abide by the legal requirements associated with these

- Users may download and print one copy of any publication from the public portal for the purpose of private study or research.

- You may not further distribute the material or use it for any profit-making activity or commercial gain

If the publication is distributed under the terms of Article $25 \mathrm{fa}$ of the Dutch Copyright Act, indicated by the "Taverne" license above, 


\title{
Endurance-Type Exercise Increases Bulk and Individual Mitochondrial Protein Synthesis Rates in Rats
}

\author{
Andrew M. Holwerda, Freek G. Bouwman, \\ and Miranda Nabben \\ Maastricht University \\ Janneau van Kranenburg and Annemie P. Gijsen \\ Maastricht University
}

\author{
Ping Wang \\ Maastricht University \\ and Maastricht University Medical Centre+
}

Jatin G. Burniston

Liverpool John Moores University

\section{Edwin C.M. Mariman and Luc J.C. van Loon Maastricht University}

\begin{abstract}
Physical activity increases muscle protein synthesis rates. However, the impact of exercise on the coordinated up- and/or downregulation of individual protein synthesis rates in skeletal muscle tissue remains unclear. The authors assessed the impact of exercise on mixed muscle, myofibrillar, and mitochondrial protein synthesis rates as well as individual protein synthesis rates in vivo in rats. Adult Lewis rats either remained sedentary $(n=3)$ or had access to a running wheel $(n=3)$ for the last 2 weeks of a 3-week experimental period. Deuterated water was injected and subsequently administered in drinking water over the experimental period. Blood and soleus muscle were collected and used to assess bulk mixed muscle, myofibrillar, and mitochondrial protein synthesis rates using gas chromatography-mass spectrometry and individual muscle protein synthesis rates using liquid chromatography-mass spectrometry (i.e., dynamic proteomic profiling). Wheel running resulted in greater myofibrillar ( $3.94 \pm 0.26$ vs. $3.03 \pm 0.15 \% /$ day; $p<.01)$ and mitochondrial $(4.64 \pm 0.24$ vs. $3.97 \pm 0.26 \% /$ day; $p<.05)$, but not mixed muscle $(2.64 \pm 0.96$ vs. $2.38 \pm 0.62 \% /$ day; $p=.71)$ protein synthesis rates, when compared with the sedentary condition. Exercise impacted the synthesis rates of 80 proteins, with the difference from the sedentary condition ranging between $-64 \%$ and $+420 \%$. Significantly greater synthesis rates were detected for F1-ATP synthase, ATP synthase subunit alpha, hemoglobin, myosin light chain- 6 , and synaptopodin-2 $(p<.05)$. The skeletal muscle protein adaptive response to endurancetype exercise involves upregulation of mitochondrial protein synthesis rates, but it is highly coordinated as reflected by the upand downregulation of various individual proteins across different bulk subcellular protein fractions.
\end{abstract}

Keywords: deuterium oxide, dynamic proteomic profiling, muscle, muscle protein synthesis, physical activity

Skeletal muscle adaptation is regulated by the balance between protein synthesis and protein breakdown rates. Muscle protein fractional synthesis rates (FSRs) can be determined by administration of stable isotope labeled amino acids and the subsequent measurement of their incorporation into muscle protein. In the 1990s, investigators first applied basic extraction techniques to show differences between bulk myofibrillar and mitochondrial protein synthesis rates in resting skeletal muscle tissue (Rooyackers et al., 1996). This approach was subsequently applied to demonstrate that, for example, endurance-type exercise more robustly increases mitochondrial protein synthesis rates (Wilkinson et al., 2008), whereas resistance-type exercise strongly increases myofibrillar protein synthesis rates (Burd

Holwerda and Bouwman contributed equally to this work. Holwerda, Bouwman, Wang, van Kranenburg, Gijsen, Mariman, and van Loon are with the Department of Human Biology, NUTRIM, Maastricht University, Maastricht, The Netherlands. Nabben is with the Department of Genetics and Cell Biology, Maastricht University, Maastricht, The Netherlands. Wang is also with the Department of Clinical Genetics, Maastricht University Medical Centre+, Maastricht, The Netherlands. Burniston is with the Research Institute for Sport and Exercise Sciences, Liverpool John Moores University, Liverpool, United Kingdom. van Loon (L.vanLoon@ maastrichtuniversity.nl) is corresponding author. et al., 2010a, 2010b; Moore et al., 2009). Even more detailed insight into individual protein translational responses has been obtained by performing two-dimensional gel electrophoresis before measuring labeled amino acid incorporation (Balagopal et al., 1994, 1997a). Using this approach, synthesis rates of key myofibrillar (Balagopal et al., 1997a, 1997b; Hasten et al., 1998) and several mitochondrial proteins (Hesketh et al., 2016; Jaleel et al., 2008) have been determined. However, the separation technique is labor intensive (13$15 \mathrm{hr}$ for one sample), technically challenging, and label quantification can require relatively large tissue samples. These limitations have restricted wide-spread application of individual protein FSR measurements.

We and others have applied deuterated water $\left({ }^{2} \mathrm{H}_{2} \mathrm{O}\right)$ to assess in vivo muscle protein synthesis rates over several days or weeks (Holwerda et al., 2018a, 2018b; Murphy et al., 2018; Robinson et al., 2011; Wilkinson et al., 2014). The endogenous labeling of nearly all (nonessential) amino acids increases total label incorporation into newly synthesized proteins, which improves analytical detectability. Recently, investigators have combined ${ }^{2} \mathrm{H}_{2} \mathrm{O}$ administration with high-throughput analytical techniques of liquid chromatography-mass spectrometry (LC-MS) to determine deuterium enrichment in hundreds of tissue-derived peptides (Hesketh 
et al., 2016; Kasumov et al., 2011; Price et al., 2012; Shankaran et al., 2016b; Wang et al., 2014; Zangarelli et al., 2006). Based upon shifts in mass spectra over time, the synthesis rates of several proteins may be assessed simultaneously (Price et al., 2012; Shankaran et al., 2016a). Within the last couple of years, this dynamic proteome profiling (DPP) approach has been applied in human and rodent studies to assess in vivo synthesis rates of several proteins in skeletal muscle tissue (Camera et al., 2017; Shankaran et al., 2016a). Simultaneous application of DPP and assessment of bulk mixed muscle, myofibrillar, and mitochondrial protein FSR in the same tissue is warranted to reveal individual protein synthetic responses that may be masked when assessing bulk protein synthesis rates. This is apparent from earlier work demonstrating that myosin heavy chain synthesis rates are $\sim 30 \%$ lower when compared with mixed muscle protein synthesis rates (Balagopal et al., 1997a). Furthermore, a quantitative comparison between the methods is required to further establish DPP as an effective approach to evaluate skeletal muscle adaptive responses. Therefore, in the present study, we assessed the impact of exercise on bulk mixed muscle, myofibrillar, and mitochondrial protein synthesis rates and applied DPP to assess individual muscle protein synthesis rates over a 3-week period in rat skeletal muscle tissue. We hypothesized that (a) protein synthesis rates of individual proteins will span a broader range in comparison with bulk protein synthesis rates, (b) exercise will induce both negative and positive differences in individual protein synthesis rates, and (c) the grouped average FSR of all individual proteins would not differ from bulk muscle FSR.

\section{Methods}

\section{Experimental Animals}

Male Lewis rats $(n=7,7 \pm 1$ months, $363 \pm 11$ g; Charles River Laboratories, Wilmington, MA) were housed in cages and maintained on 12-hr light/12-hr dark cycles. Rats were sacrificed after an intraperitoneal injection of sodium pentobarbital $(150 \mathrm{mg} / \mathrm{kg}$ body mass). All procedures were approved by the Animal Experiments Committee at Maastricht University and were in accordance with the Code of Conduct of the Central Animal Experiments Committee.

\section{Experimental Protocol}

Six rats received standard chow diet and water ad libitum and underwent the 3 -week ${ }^{2} \mathrm{H}_{2} \mathrm{O}$ protocol. During the first week, all rats remained sedentary to acclimatize to the experimental setting, including ${ }^{2} \mathrm{H}_{2} \mathrm{O}$ administration. Starting after Week 1, three rats received cage access to a running wheel, whereas the other three rats remained sedentary. Lewis rats voluntarily perform wheel running for distances of 4,500-10,000 m/day (Makatsori et al., 2003; Werme et al., 1999). After the 3-week experimental period, the animals were sacrificed, and blood and muscle samples were collected and stored as previously described (Holwerda et al., 2018b). A separate rat, housed under identical (sedentary) conditions, was sacrificed to provide unlabeled control soleus muscle for LC-MS/MS analysis.

\section{${ }^{2} \mathrm{H}_{2} \mathrm{O}$ Dosing Protocol}

The ${ }^{2} \mathrm{H}_{2} \mathrm{O}$ dosing protocol was adopted from previous study (Neese et al., 2002) and consisted of one intraperitoneal injection of $70 \%$ deuterium oxide (Cambridge Isotopes Laboratories, Tewksbury, MA) at $0.02 \mathrm{ml} / \mathrm{g}$ body mass and access to $4 \%$ deuterium-enriched drinking water.

\section{Plasma Free ${ }^{2} \mathrm{H}-A$ lanine and Body Water ${ }^{2} \mathrm{H}$ Enrichments}

Plasma amino acid enrichments were determined by gas chromatography-mass spectrometry (GC-MS) as described previously (Holwerda et al., 2018b). Body water ${ }^{2} \mathrm{H}$ enrichments were determined by dividing plasma ${ }^{2} \mathrm{H}$-alanine enrichments by 3.7 , which is the labeling factor between body water and alanine (Holwerda et al., 2018b; Wilkinson et al., 2014).

\section{Bulk Protein-Bound ${ }^{2} \mathrm{H}$-Alanine Enrichment}

Bulk mixed muscle, myofibrillar, and mitochondrial protein fractions were isolated from muscle samples, and protein-bound ${ }^{2} \mathrm{H}$-alanine enrichments were measured using GC-MS, as described previously (Churchward-Venne et al., 2019; Holwerda et al., 2016, 2018b).

\section{LC-MS Analysis}

A separate piece of muscle underwent a trypsin digestion protocol as previously described (Qiao et al., 2019) to cleave peptides. The peptide mixture was loaded onto an LC-MS/MS, configured as described previously (Qiao et al., 2019; Vogel et al., 2019).

\section{Label-Free Quantitation of Protein Abundances}

Progenesis QI for proteomics (Waters, Milford, MA) was used to perform label-free quantitation as described previously (BowdenDavies et al., 2015; Burniston et al., 2014; Camera et al., 2017; Sollanek et al., 2017). Log-transformed MS data were normalized by intersample abundance ratio, and relative protein abundances were calculated using nonconflicting peptides only. Spectra generated from Mass Spectrometer 2 (MS2) were exported in Mascot generic format and searched against the Swiss-Prot database (2018.7) using a locally implemented Mascot server (version 2.2.03; www.matrixscience.com). The Mascot output, restricted to nonhomologous protein identifications (false discovery rate $<$ $1 \%$ ), was recombined with MS profile data in Progenesis QI (Burniston et al., 2014).

\section{FSR Calculations-Bulk Muscle Protein Fractions}

Bulk mixed muscle, myofibrillar, and mitochondrial protein FSRs were calculated over the 3-week deuterium water administration period using a first-order kinetics equation (Shankaran et al., 2016a):

$$
\operatorname{FSR}(\% / \text { day })=\frac{-\ln (1-f)}{t} .
$$

We applied a first-order kinetics equation to account for the prolonged labeling period and potential differences in the synthetic rates between protein fractions and individual proteins. $f$ is the cumulative fractional synthesis, which was determined by dividing the proteinbound ${ }^{2} \mathrm{H}$-alanine enrichment in the 3 -week muscle samples by the free ${ }^{2} \mathrm{H}$-alanine enrichment in the 3 -week plasma samples. $t$ represents the time (21 days).

\section{FSR Calculations-Dynamic Proteomic Profiling}

Protein synthesis rates were calculated from peptide mass isotopomer abundance data extracted from spectra generated from Mass 
Spectrometer 1 (MS1) using Progenesis QI (Waters), as described previously (Camera et al., 2017). The rate of decay $(k)$ of the molar fraction (MF0) of the monoisotopic peak (M0) was calculated as a first-order exponential spanning the beginning $(t 0)$ to end $(t)$ of the experimental period.

$$
\begin{aligned}
\mathrm{MF} 0 & =\frac{\mathrm{M} 0}{\mathrm{M} 0+\mathrm{M} 1+\mathrm{M} 2+\mathrm{M} 3}, \\
k & =\frac{1}{t-t 0} \cdot-\ln \left(\frac{\mathrm{MFO}_{t}}{\mathrm{MF}_{t 0}}\right) .
\end{aligned}
$$

The FSR (\%/day) was derived by dividing $k$ by body water ${ }^{2} \mathrm{H}$ enrichment $(p)$ multiplied by the number $(n)$ of ${ }^{2} \mathrm{H}$ exchangeable $\mathrm{H}-\mathrm{C}$ bonds present in each peptide. $n$ was calculated for each peptide using existing data on amino acid ${ }^{2} \mathrm{H}$ labeling in humans (Price et al., 2012).

$$
\operatorname{FSR}(\% / \text { day })=\frac{k}{(n \cdot p)} .
$$

\section{Statistical Analysis}

Data are expressed as means $\pm S D$ s. Independent two-tailed Student $t$ tests were used to compare plasma ${ }^{2} \mathrm{H}$-alanine enrichments, estimated body water ${ }^{2} \mathrm{H}$ enrichments, average bulk protein synthesis rates, and grouped (i.e., total, mitochondrial, myofibrillar) individual protein synthesis rates. A one-way between-group analysis of variance was used to compare individual protein differences between the sedentary and exercise conditions. Statistical significance was set at $p<.05$. The false discovery rate $Q$ value was calculated to control multiple testing. Unless otherwise stated, calculations were performed using Excel (version 16; Microsoft, Redmond, WA) or SPSS (version 24; IBM, Armonk, NY). Pearson $r$ product moment correlation analysis was used to examine the linear relationship between bulk mixed muscle, myofibrillar, and mitochondrial FSRs with grouped averages of the individual protein FSRs, which were assigned to subcellular protein fraction (i.e., total, myofibrillar, and mitochondrial).

\section{Results}

\section{${ }^{2} \mathrm{H}_{2} \mathrm{O}$ Precursor Labeling}

The ${ }^{2} \mathrm{H}_{2} \mathrm{O}$ dosing protocol resulted in plasma-free ${ }^{2} \mathrm{H}$-alanine enrichments of $8.16 \pm 0.09$ and $8.04 \pm 0.05$ mole percent excess (MPE) at Day 21 in the sedentary and exercise groups, respectively $(p=.10)$. The corresponding body water deuterium enrichments averaged $2.21 \pm 0.02 \%$ and $2.17 \pm 0.02 \%$ in the sedentary and exercise groups, respectively $(p=.10)$.

\section{FSRs of Bulk Mixed Muscle, Myofibrillar, and Mitochondrial Protein}

Bulk mixed muscle protein-bound ${ }^{2} \mathrm{H}$-alanine measured by $\mathrm{GC}$ MS averaged 3.37 $\pm 0.93 \mathrm{MPE}$ in the exercise group and did not differ $(p=.79)$ from $3.18 \pm 0.66 \mathrm{MPE}$ in the sedentary group. Bulk myofibrillar protein-bound ${ }^{2} \mathrm{H}$-alanine enrichments averaged $4.52 \pm 0.19 \mathrm{MPE}$ in the exercise group, which was significantly $(p<.05)$ greater than $3.84 \pm 0.18 \mathrm{MPE}$ in the sedentary group. Bulk mitochondrial protein-bound ${ }^{2} \mathrm{H}$-alanine enrichments averaged $5.01 \pm 0.12 \mathrm{MPE}$ in the exercise group, which was significantly

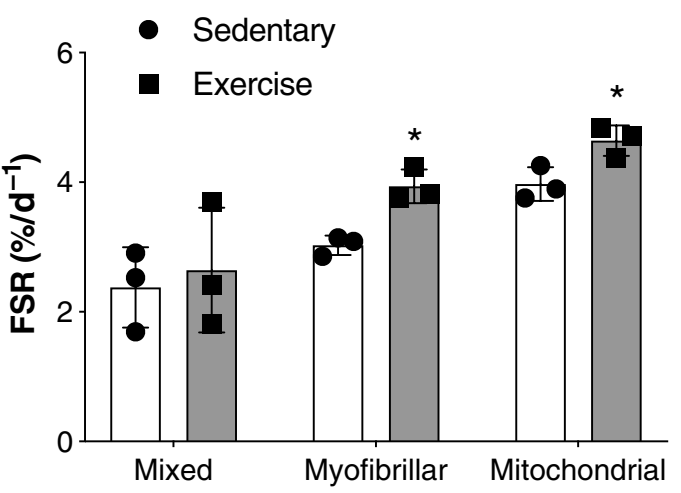

Figure 1 - Mixed muscle, myofibrillar, and mitochondrial protein fractional synthesis rates (FSRs, \%/day) assessed in the soleus muscle of Lewis rats that either had access to a cage running wheel (exercise, $n=3$ ) or were restricted to sedentary conditions (sedentary, $n=3$ ) for the last 2 weeks of a 3-week assessment period. Values are presented as means \pm $S D$ s. *Significantly different from the sedentary condition $(P<.05)$.

$(p<.05)$ greater than $4.62 \pm 0.21 \mathrm{MPE}$ in the sedentary group. Mixed muscle protein FSRs (Figure 1) did not differ between the exercising $(2.64 \pm 0.96 \% /$ day $)$ and sedentary rats $(2.38 \pm 0.62 \% /$ day; $p=.71$ ). Myofibrillar muscle protein FSR (Figure 1) was $\sim 30 \%$ greater in the exercise group $(3.94 \pm 0.26 \% /$ day $)$ when compared with the sedentary group $(3.03 \pm 0.15 \% /$ day; $p<.01)$. Mitochondrial muscle protein FSR (Figure 1) was $\sim 17 \%$ greater in the exercise group $(4.64 \pm 0.24 \% /$ day $)$ when compared with the sedentary group $(3.97 \pm 0.26 \% /$ day; $p<.05)$.

\section{Individual Muscle Protein Abundances}

Label-free profiling was performed on 256 proteins that had at least one unique peptide detected in each animal. The dynamic range of the label-free analysis spanned six orders of magnitude. The most abundant muscle protein was myosin light chain 3 (MYL3; relative protein abundances $=9.89 \mathrm{E}+08$ ), and the least abundant muscle protein detected was myosin heavy chain 9 (MYH9; relative protein abundances $=3.61 \mathrm{E}+04)$. The normalized abundances of three proteins (musculoskeletal embryonic nuclear protein 1 [MUSTN1], adenylate kinase isoenzyme 1 [KAD1], and 60S ribosomal protein L32 [RPL32]) were statistically $(p<.05)$ greater in the exercise compared with sedentary control samples, though with a high false discovery rate $(0.48)$.

\section{FSRs of Individual Muscle Proteins}

Based on our selection criteria, we were able to assess the FSRs of 108 out of 256 identified proteins $(42 \%)$, which resided in the muscle cytosolic, mitochondrial, myofibrillar, and nuclear fractions, as well as in residual blood (Table 1). The weighted average FSR of all individual proteins in both groups was $2.59 \pm 0.69 \% /$ day, which was not statistically different from bulk mixed muscle protein FSR measured by GC-MS analysis $(p=.91)$. The rank order of the synthesis rates for these 108 proteins is displayed in Figure 2. FSR of the detected individual proteins was lowest in histone $\mathrm{H} 2 \mathrm{~A}$ type $1-\mathrm{C}(\mathrm{H} 2 \mathrm{~A} 1 \mathrm{C} ; 0.48 \pm 0.09 \% /$ day $)$ and highest in alpha-2-HS-glycoprotein (FETUA; 9.25 $\pm 0.38 \% /$ day). The average FSR across individual mitochondrial proteins demonstrated a strong, positive correlation with bulk mitochondrial FSR $(p=.03, r=.73$, Figure 3c) 


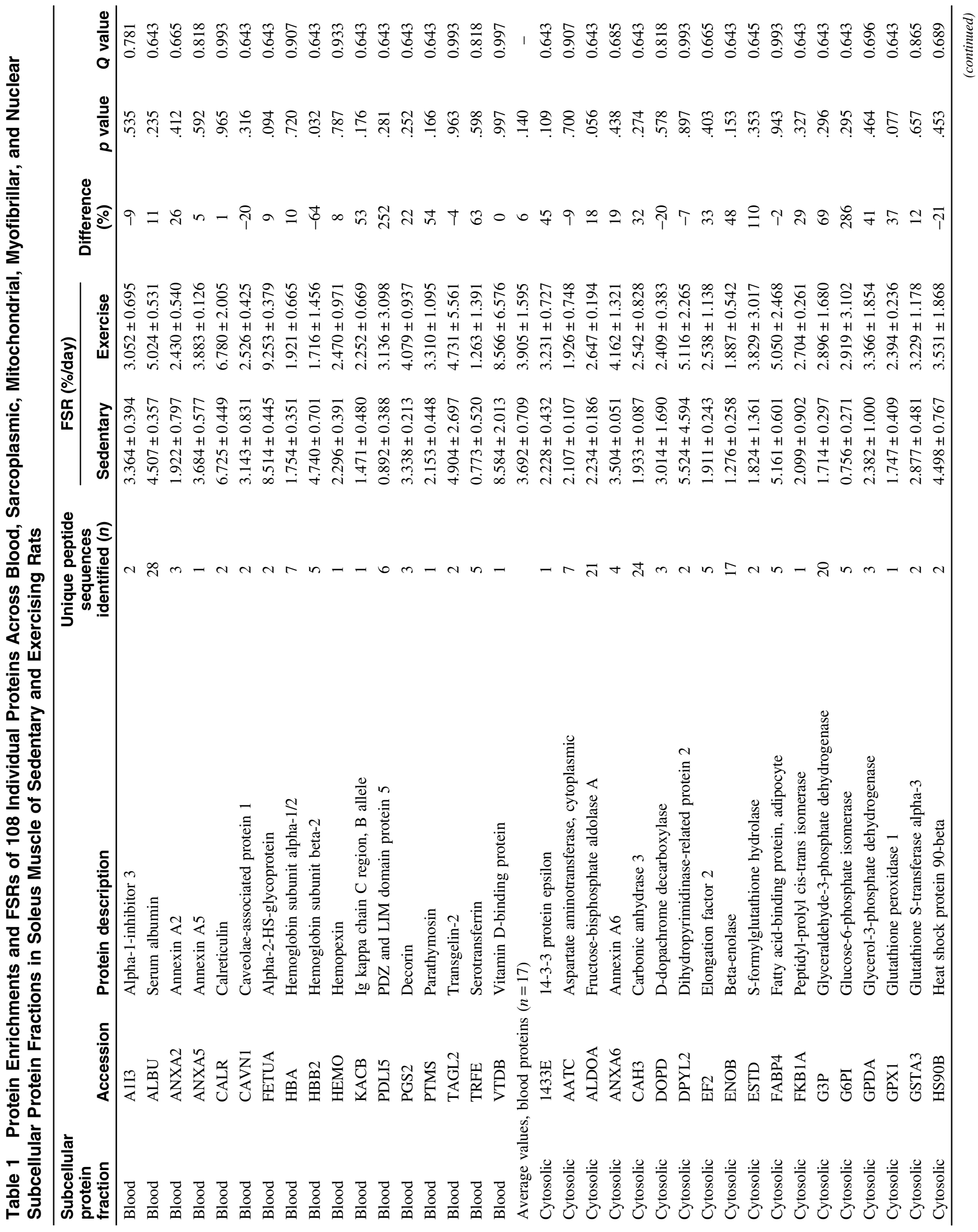




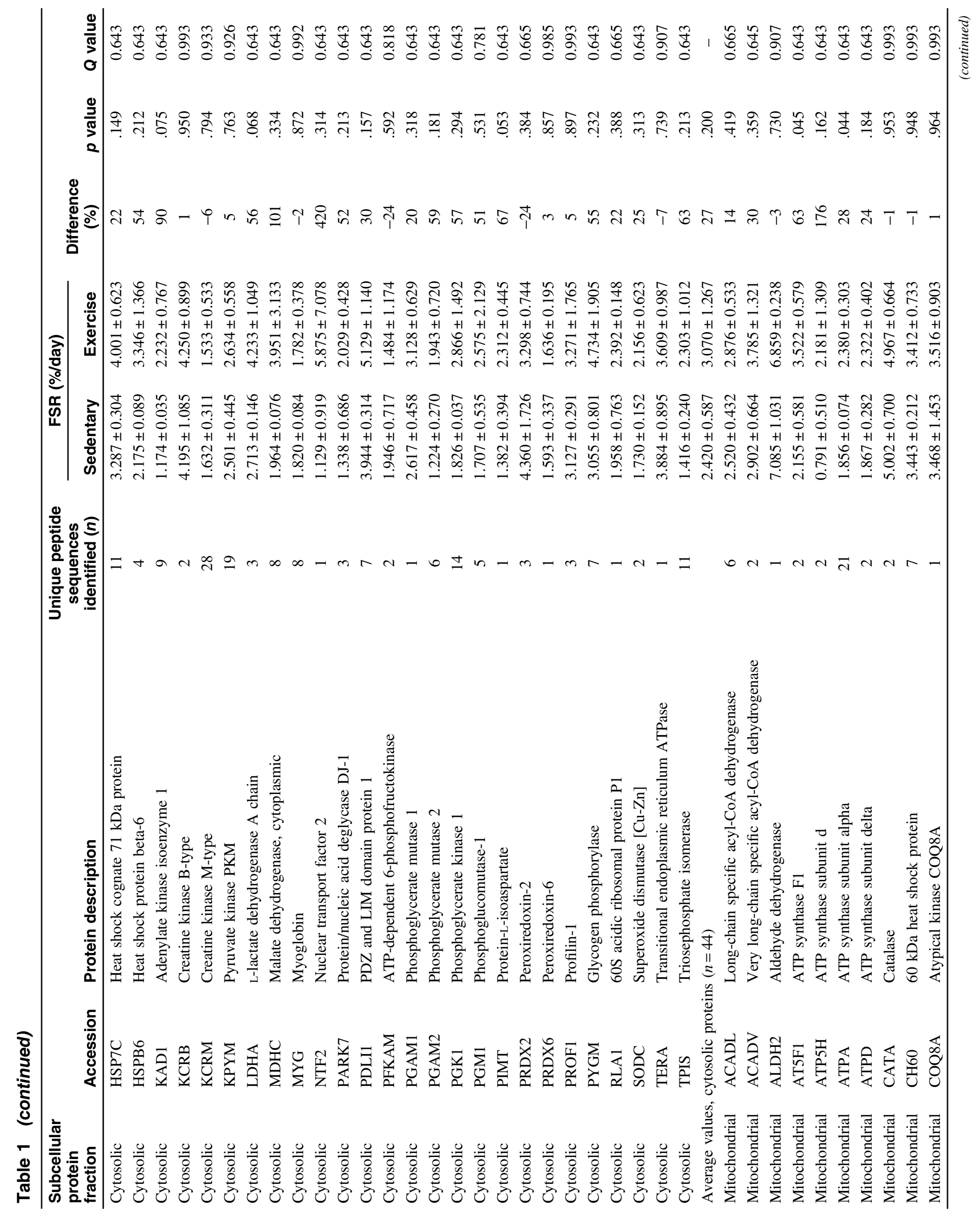




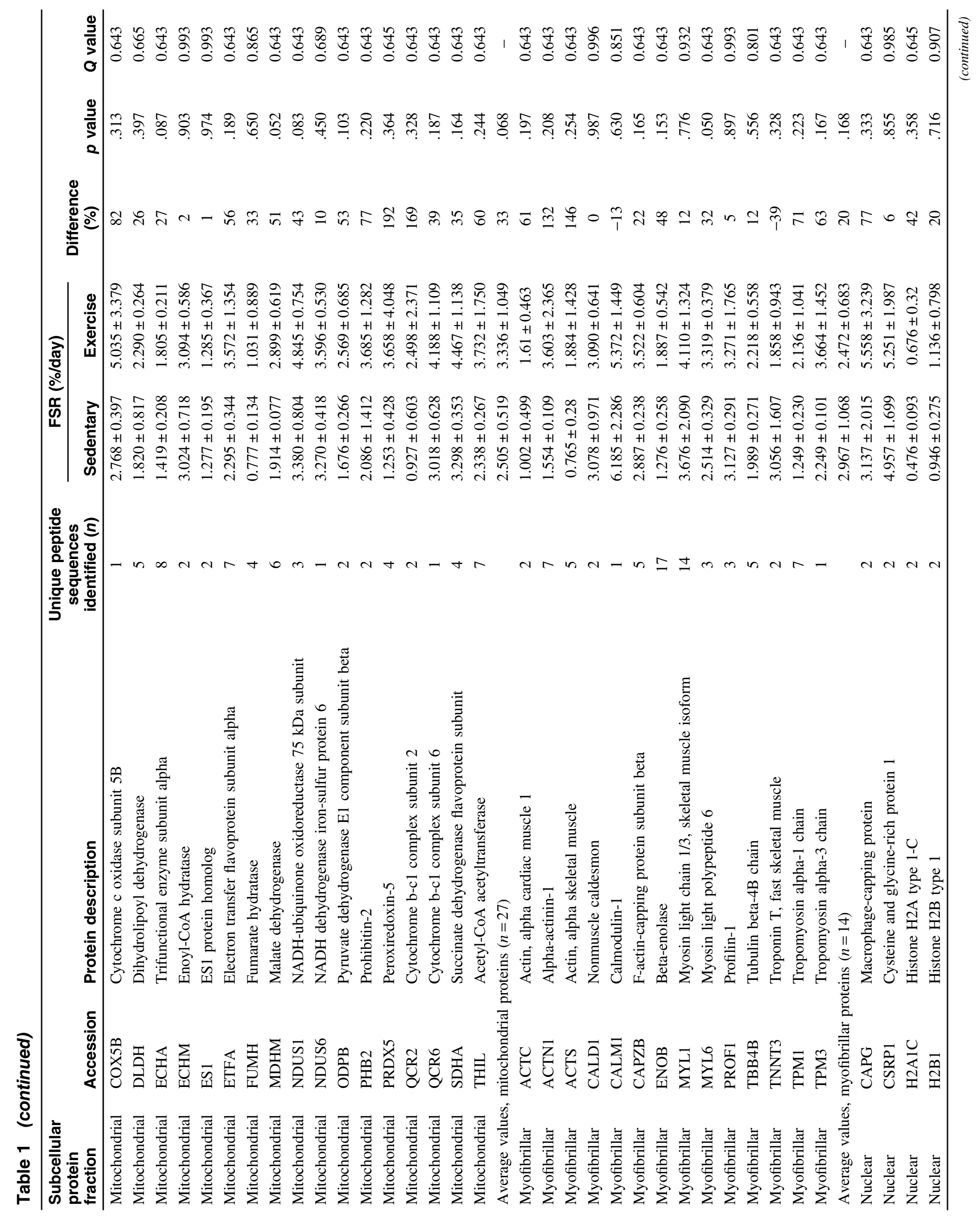




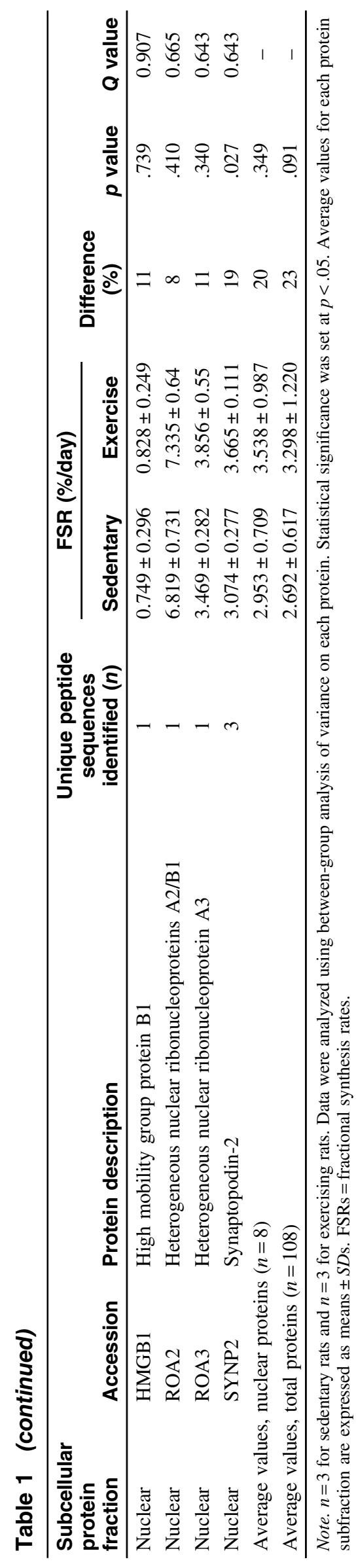

IJSNEM Vol. 30, No. 2, 2020 

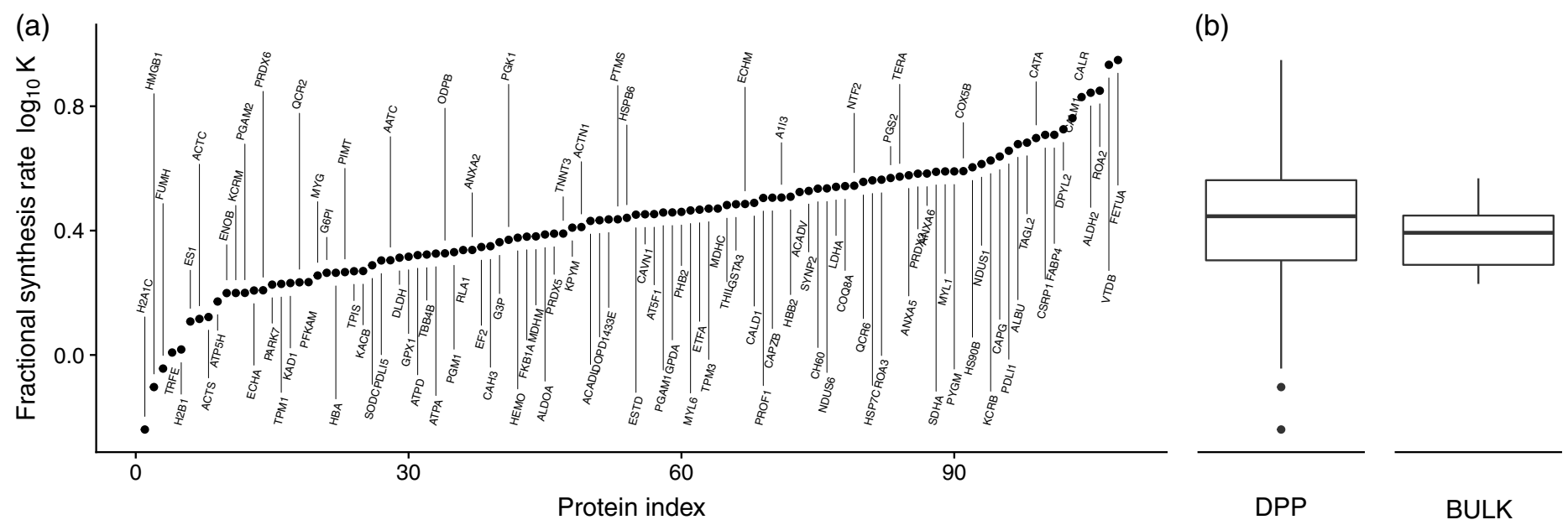

Figure 2 - Rank order of individual protein synthesis rates in rat soleus muscle. Panel (a) displays the mean rate constant (k) for the synthesis of each protein ranked from lowest to highest during the 3-week experimental period. Labels indicate the UniProt Knowledgebase identifiers for the detected proteins. Panel (b) displays box plots presenting the average (median and interquartile range) rate constant of synthesis of proteins that were analyzed using DPP and the BULK during the 3-week experimental period. Independent two-tailed Student $t$ test found no significant $(P=.91)$ difference in the average rate of synthesis of the grouped individual proteins $(n=108)$ when compared with BULK. DPP $=$ dynamic proteome profiling; BULK $=$ bulk mixed muscle protein fraction.
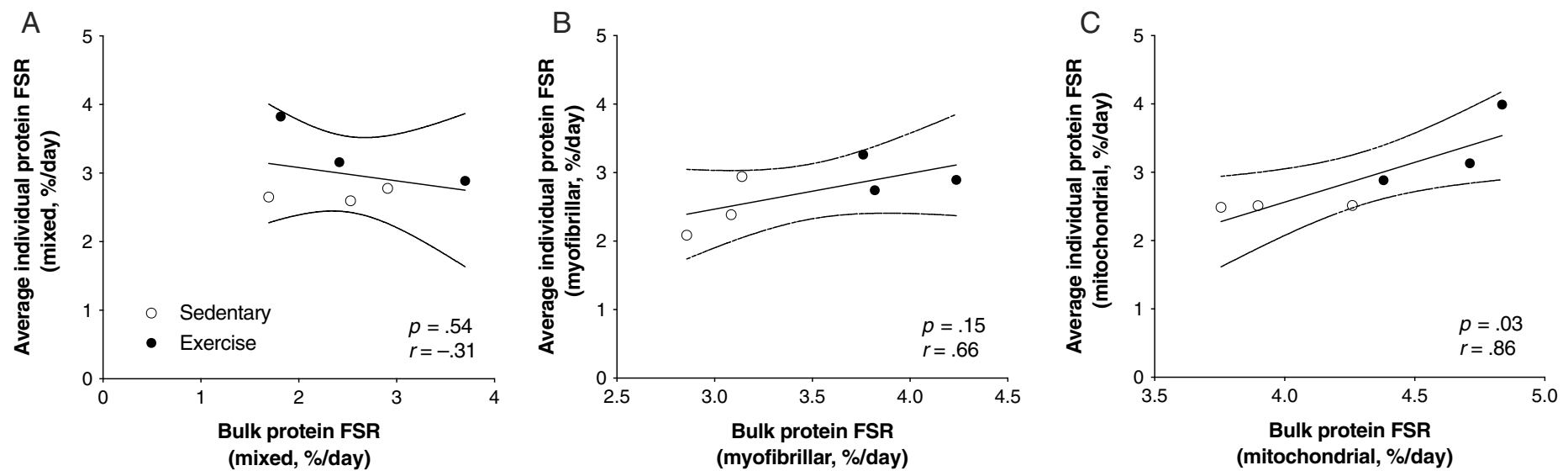

Figure 3 - Correlations between the averages of grouped individual protein fractional synthesis rates (FSRs) and the corresponding bulk mixed muscle (a), myofibrillar (b), and mitochondrial (c) protein fractions FSRs. The solid line indicates the linear regression line of best fit, and the dashed lines indicate the $95 \%$ confidence interval. A significant positive correlation was observed between methods for mitochondrial proteins $\left(p=.03, R^{2}=.73\right)$.

\section{Individual Protein Synthetic Responses to Exercise}

Exercise appeared to impact the synthesis rates of the majority of identified proteins. Eighty proteins demonstrated a difference in FSR greater than $+10 \%$ or less than $-10 \%$ between muscles of sedentary and exercising animals, and the percentage difference of myofibrillar and mitochondrial proteins relative to sedentary conditions ranged from $-64 \%$ to $+420 \%$ (Figure 4 ). When all detected proteins were averaged, exercise did not result in significantly higher protein synthesis rates when compared with sedentary $(3.30 \pm 1.22$ vs. $2.69 \pm 0.62 \%$ /day, respectively, $p=$ $.09)$. When proteins were grouped into subcellular protein fraction, exercise did not result in significantly higher mitochondrial protein synthesis rates when compared with sedentary $(3.34 \pm$ 1.05 vs. $2.51 \pm 0.52 \% /$ day, respectively, $p=.07$ ). At the individual protein level, exercise resulted in greater synthesis rates $(p<.05)$ of F1-ATP synthase (AT5F1), ATP synthase subunit alpha (ATPA), hemoglobin (HBB2), myosin light chain 6 (MYL6), and synaptopodin-2 (SYNP2) (Figure 5).

\section{Discussion}

We observed that bulk myofibrillar and mitochondrial protein synthesis rates were greater in the soleus muscle tissue of exercising rats when compared with their sedentary littermates. Exercise impacted the synthesis rates of 80 out of 108 detected proteins, with the response ranging between $-64 \%$ to $+420 \%$ when expressed relative to the sedentary condition.

Bulk myofibrillar and mitochondrial protein synthesis rates were, respectively, $\sim 30 \%$ higher and $\sim 17 \%$ higher in the exercising rats when compared with the sedentary rats (Figure 1). Our findings align with previous studies in rodents that have applied a 


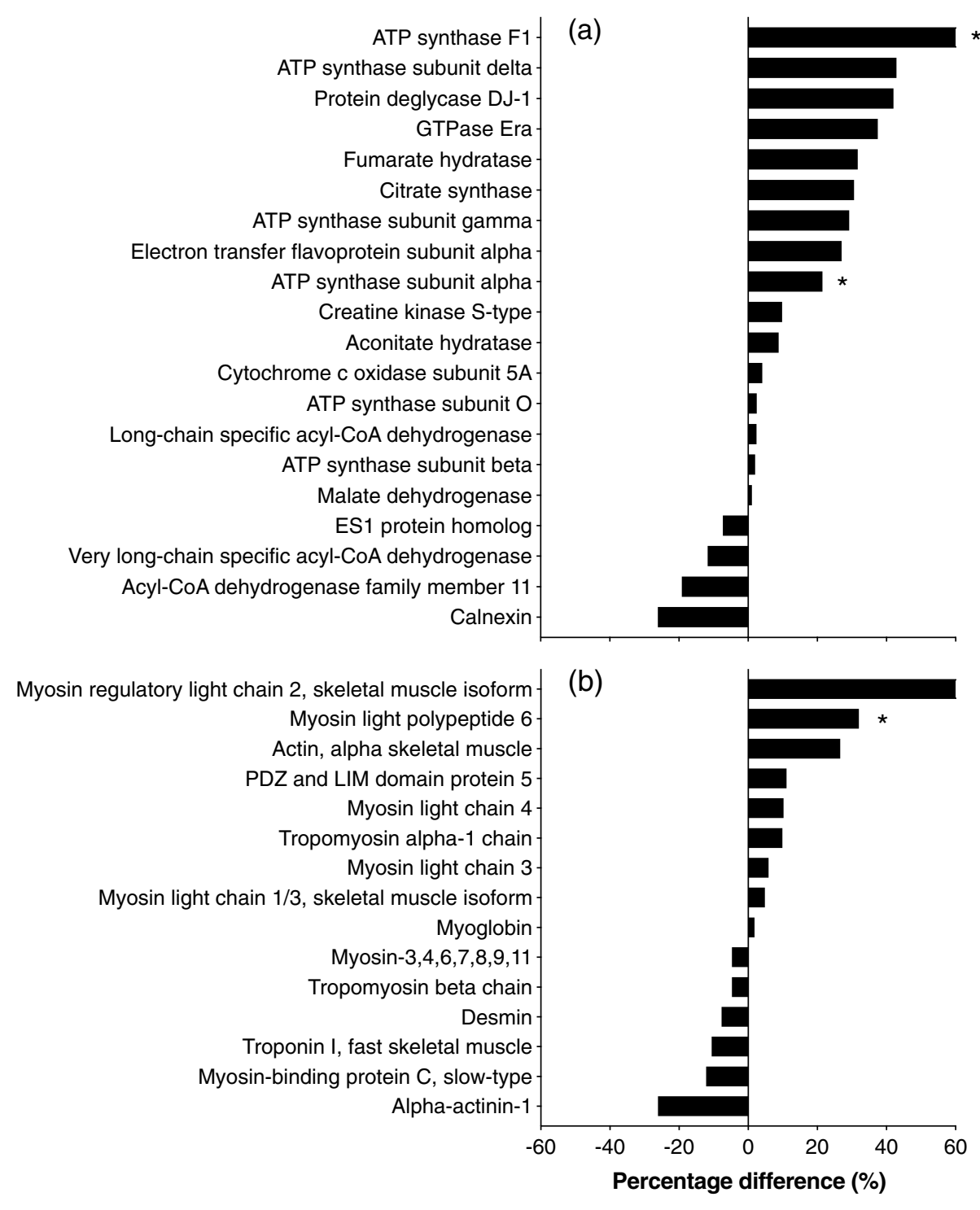

Figure 4 - Percentage difference in fractional synthesis rates (FSRs) of individual mitochondrial (a) and myofibrillar (b) proteins assessed in the soleus muscle of Lewis rats that either had access to a cage running wheel (exercise, $n=3$ ) or were restricted to sedentary conditions (sedentary, $n=3$ ) over a 3-week experimental period. Presented proteins demonstrated a difference in FSR greater than $+10 \%$ or less than $-10 \%$ between sedentary and exercise rats. Values are presented as the average percentage difference of FSR in the exercise group compared with the sedentary group. $*$ Significantly different in exercise versus sedentary $(P<.05)$.

variety of isotope-based methods to demonstrate the robust anabolic impact of chronic and acute exercise on muscle protein synthesis rates (Gasier et al., 2010; Kubica et al., 2005; Mosoni et al., 1995; Munoz et al., 1994; Wong \& Booth, 1990). However, exercise did not result in significantly higher mixed muscle protein synthesis rates when compared with the sedentary rats (Figure 1). This finding is in contrast with some (Gasier et al., 2010; Kubica et al., 2005; Mosoni et al., 1995; Munoz et al., 1994; Ogasawara et al., 2014, 2016; Wong \& Booth, 1990), but not all (Katzeff et al., 1995; Wang et al., 2017), studies that have assessed the impact of exercise on mixed muscle protein synthesis rates in rats. The absence of a response may be explained by a relatively low (or negative) synthetic response of proteins residing outside of the myofibrillar and mitochondrial subfractions. Nonmyofibrillar and mitochondrial proteins have been estimated to comprise 30-40\% of all muscle proteins (Balagopal et al., 1996). It has also been demonstrated that synthesis of myosin heavy chain, one of the most abundant muscle proteins $(\sim 25 \%)$, only contributes $\sim 18 \%$ to mixed muscle protein synthesis rates (Balagopal et al., 1997a). Theoretically, a $\sim 30 \%$ increase in myosin heavy-chain synthesis would only increase mixed muscle protein synthesis by $\sim 5-6 \%$, which could be masked by the co-occurring responses of other proteins (Balagopal et al., 1997a).

We performed DPP by measuring the mass spectra of hundreds of muscle-derived peptides using high-throughput tandem MS. Individual protein synthesis rates in the present study align well with absolute individual protein synthesis rates reported in a recent study that applied a comparable DPP approach in rat muscle (Shankaran et al., 2016b). The individual protein synthesis rates spanned a broader range than the absolute bulk protein synthesis rates (Figure 2b). We observed that the synthetic rates of key mitochondrial proteins, such as cytochrome-c oxidase $(2.77 \pm 0.40 \% /$ day $)$ and 


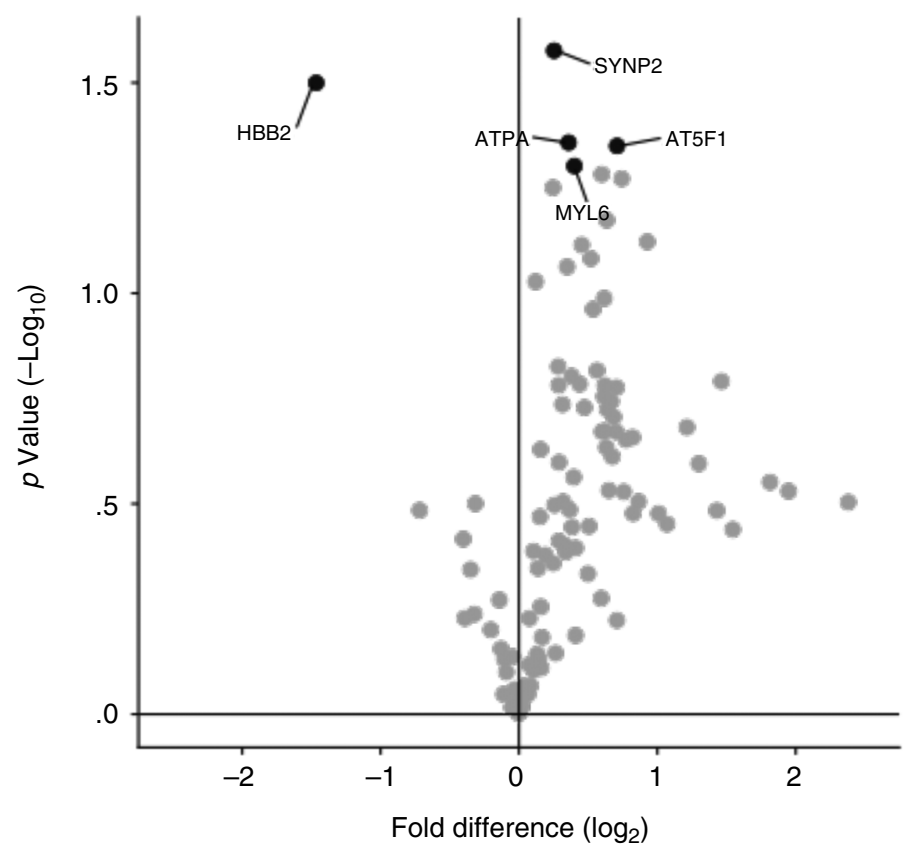

Figure 5 - Volcano plot presenting the average fold changes in synthesis rates of individual proteins of the exercise group compared with the sedentary group. $p$ values were calculated using between-subject analysis of variance. Proteins are represented in black if they exhibited a statistically significant $(p<.05$, all false discovery rate $=0.64)$ change when compared with the sedentary condition. AT5F1 = F1-ATP synthase; ATPA = ATP synthase subunit alpha; HBB2 = hemoglobin; MYL6= myosin light chain-6; SYNP2 = synaptopodin-2.

succinate dehydrogenase $(3.30 \pm 0.35 \% /$ day $)$, were fourfold higher when compared with key myofibrillar proteins, such as $\alpha$-actin $(0.77 \pm 0.28 \% /$ day $)$ and $\alpha$-actinin- $1(1.55 \pm 0.11 \% /$ day $)$, which align with previous literature (Jaleel et al., 2008). The FSR of proteins assigned to "mitochondrion" had a strong, positive correlation with bulk mitochondrial protein FSR (Figure 3c). However, we did not detect a correlation in the mixed muscle or myofibrillar protein fractions (Figure 3a and 3b). The discrepancy may be explained by the greater detection of mitochondrial proteins $(n=27)$ in comparison with myofibrillar proteins $(n=14)$. Furthermore, certain highly abundant proteins (e.g., collagen) were not detected using DPP, but were likely captured in the bulk mixed protein isolation. Strict categorization of some proteins known to reside in more than one cellular compartment or translocate between compartments (e.g., heat shock proteins) may have also contributed to the absence of a correlation between methods for myofibrillar proteins.

Exercise seemed to impact the synthesis rates of the majority of detected proteins (80/108), with the response ranging from $-64 \%$ to $+420 \%$ relative to sedentary conditions. Notably, we reveal that exercise resulted in significantly greater synthesis rates of F1-ATP synthase and ATP synthase subunit alpha when compared with the sedentary group (Table 1 and Figure 5). Furthermore, several proteins within the tricarboxylic acid cycle and electron transport system demonstrated 35-140\% higher protein synthesis rates in the exercise group when compared with the sedentary group (Figure 4a). Increased synthesis rates of these proteins, and ATP synthase in particular, likely contribute to the increase in muscle oxidative capacity observed over more prolonged endurance-type exercise training (Burniston \& Hoffman, 2011; Hesketh et al., 2016; Holloszy et al., 1970). However, we did not detect significantly greater abundances of these proteins in the present study, which is likely due to low subject number or the mere 2 -week exercise intervention. We chose to assess protein synthetic responses in the soleus muscle primarily due to the high Type I muscle fiber content and aerobic nature of wheel running exercise. As soleus muscle may possess a greater sensitivity to induce transcriptional and/or protein synthetic responses to physical (in)activity when compared with other muscles (e.g., plantaris or tibialis anterior; Miller et al., 2019), we should be careful when translating these findings to other muscle groups.

Bulk protein FSR assessment and DPP provide distinct advantages and disadvantages and can complement each other. For example, DPP allows identification and assessment of protein synthesis rates within subcellular protein fractions, which is valuable for resolving more specific physiological issues, such as characterizing how key mitochondrial proteins (e.g., ATP synthase) respond to physical (in)activity, aging, and/or disease. Characterizing the coordinated regulation of individual mitochondrial proteins is of particular relevance given the gap in our understanding of mitochondrial protein adaptation due to the challenges of isolating a pure mitochondrial fraction from muscle tissue (Burd et al., 2015). Despite this advantage, we and others have been able to assess the synthesis rates of only 100-150 individual proteins in skeletal muscle tissue. This number is equivalent to merely $2 \%$ of the approximately 5,500 proteins present in the skeletal muscle proteome (Gonzalez-Freire et al., 2017). Although the top 100 detectable muscle proteins have been suggested to represent $85 \%$ of total muscle protein (Geiger et al., 2013), the detectable proteins cannot currently be localized to the different muscle fiber types or to nonmuscle tissue (e.g., fat, connective tissue), which likely respond differently to stimuli. The methodological approach (e.g., sample preparation, instrument sensitivity) may be modified to detect targeted peptide/protein families, which would be useful for resolving some of these issues in the future. On the other hand, bulk protein FSR assessment provides an average representation of all proteins residing in the isolated fraction. Therefore, bulk protein FSR assessment can be applied to reveal the regulation of bulk muscle protein abundance. Acquiring this information can deepen our understanding of skeletal muscle mass regulation to physical (in)activity, nutrition, aging, and disease. Considering the high cost of DPP and the rather limited number of proteins detected in muscle tissue, it is evident that, in most cases, the assessment of bulk protein FSR provides sufficient insight into the muscle protein synthetic response to various interventions.

Limitations of the current study must be acknowledged. First, the relatively low subject numbers may have resulted in Type II errors among comparisons between bulk mixed muscle protein FSR and grouped individual protein FSR data, as well as the lack of a difference in mixed muscle protein FSR between muscle tissues collected from the sedentary and exercising rats. Second, we allowed the exercising rats to run with no restriction but did not quantitate exercise duration or intensity.

In conclusion, bulk mitochondrial, but not mixed muscle or myofibrillar, protein synthesis rates align well with the averages of grouped individual protein FSRs from the same subcellular fraction. The impact of exercise on individual muscle proteins is highly coordinated as reflected by the simultaneous up- and downregulation of several individual proteins residing in different muscle protein fractions.

\section{Acknowledgments}

We thank Joan Senden, Joy Goessens, and Ronny Mohren for their expert analytical support and discussions. The authors declare no conflicts of interest. A.M. Holwerda, F.G. Bouwman, M. Nabben, and L.J.C. van Loon 
designed the research; A.M. Holwerda and M. Nabben conducted the research; F.G. Bouwman, J.G. Burniston, P. Wang, J. van Kranenburg, and A.P. Gijsen analyzed the data; A.M. Holwerda and J.G. Burniston performed the statistical analysis; all authors contributed to data interpretation; and A.M. Holwerda, F.G. Bouwman, J.G. Burniston, E.C.M. Mariman, and L.J.C. van Loon wrote the paper and hold primary responsibility for the final content. All authors read and approved the final manuscript.

\section{References}

Balagopal, P., Ford, G.C., Ebenstein, D.B., Nadeau, D.A., \& Nair, K.S. (1996). Mass spectrometric methods for determination of [13C]Leucine enrichment in human muscle protein. Analytical Biochemistry, 239(1), 77-85. PubMed ID: 8660628 doi:10.1006/abio.1996.0293

Balagopal, P., Ljungqvist, O., \& Nair, K.S. (1997a). Skeletal muscle myosin heavy-chain synthesis rate in healthy humans. American Journal of Physiology, 272(1, Pt. 1), E45-E50.

Balagopal, P., Nair, K.S., \& Stirewalt, W.S. (1994). Isolation of myosin heavy chain from small skeletal muscle samples by preparative continuous elution gel electrophoresis: Application to measurement of synthesis rate in human and animal tissue. Analytical Biochemistry, 221(1), 72-77. PubMed ID: 7985807 doi:10.1006/abio.1994.1381

Balagopal, P., Rooyackers, O.E., Adey, D.B., Ades, P.A., \& Nair, K.S. (1997b). Effects of aging on in vivo synthesis of skeletal muscle myosin heavy-chain and sarcoplasmic protein in humans. American Journal of Physiology, 273(4, Pt. 1), E790-E800.

Bowden-Davies, K., Connolly, J., Burghardt, P., Koch, L.G., Britton, S.L., \& Burniston, J.G. (2015). Label-free profiling of white adipose tissue of rats exhibiting high or low levels of intrinsic exercise capacity. Proteomics, 15(13), 2342-2349. PubMed ID: 25758023 doi:10.1002/pmic.201400537

Burd, N.A., Holwerda, A.M., Selby, K.C., West, D.W., Staples, A.W., Cain, N.E., . . Phillips, S.M. (2010a). Resistance exercise volume affects myofibrillar protein synthesis and anabolic signalling molecule phosphorylation in young men. The Journal of Physiology, 588(Pt. 16), 3119-3130. doi:10.1113/jphysiol.2010.192856

Burd, N.A., Tardif, N., Rooyackers, O., \& van Loon, L.J.C. (2015). Optimizing the measurement of mitochondrial protein synthesis in human skeletal muscle. Applied Physiology, Nutrition, and Metabolism, 40(1), 1-9. PubMed ID: 25494678 doi:10.1139/apnm-2014-0211

Burd, N.A., West, D.W., Staples, A.W., Atherton, P.J., Baker, J.M., Moore, D.R., . . . Phillips, S.M. (2010b). Low-load high volume resistance exercise stimulates muscle protein synthesis more than high-load low volume resistance exercise in young men. PLoS One, 5(8), e12033. doi:10.1371/journal.pone.0012033

Burniston, J.G., Connolly, J., Kainulainen, H., Britton, S.L., \& Koch, L.G. (2014). Label-free profiling of skeletal muscle using high-definition mass spectrometry. Proteomics, 14(20), 2339-2344. PubMed ID: 25065561 doi:10.1002/pmic.201400118

Burniston, J.G., \& Hoffman, E.P. (2011). Proteomic responses of skeletal and cardiac muscle to exercise. Expert Review Proteomics, 8(3), 361-377. doi:10.1586/epr.11.17

Camera, D.M., Burniston, J.G., Pogson, M.A., Smiles, W.J., \& Hawley, J.A. (2017). Dynamic proteome profiling of individual proteins in human skeletal muscle after a high-fat diet and resistance exercise. The FASEB Journal, 31(12), 5478-5494. doi:10.1096/fj.201700531R

Churchward-Venne, T.A., Pinckaers, P.J.M., Smeets, J.S.J., Peeters, W.M., Zorenc, A.H., Schierbeek, H., . . . van Loon, L.J.C. (2019). Myofibrillar and mitochondrial protein synthesis rates do not differ in young men following the ingestion of carbohydrate with whey, soy, or leucine-enriched soy protein after concurrent resistance- and endurance-type exercise. The Journal of Nutrition, 149(2), 210 220. doi:10.1093/jn/nxy251

Gasier, H.G., Fluckey, J.D., \& Previs, S.F. (2010). The application of ${ }^{2} \mathrm{H}_{2} \mathrm{O}$ to measure skeletal muscle protein synthesis. Nutrition \& Metabolism, 7, 31. PubMed ID: 20409307 doi:10.1186/1743-7075-7-31

Geiger, T., Velic, A., Macek, B., Lundberg, E., Kampf, C., Nagaraj, N., . . Mann, M. (2013). Initial quantitative proteomic map of 28 mouse tissues using the SILAC mouse. Molecular \& Cellular Proteomics, 12(6), 1709-1722. PubMed ID: 23436904 doi:10.1074/ mcp.M112.024919

Gonzalez-Freire, M., Semba, R.D., Ubaida-Mohien, C., Fabbri, E., Scalzo, P., Højlund, K., . . . Ferrucci, L. (2017). The human skeletal muscle proteome project: A reappraisal of the current literature. Journal of Cachexia, Sarcopenia and Muscle, 8(1), 5-18. doi:10.1002/jcsm. 12121

Hasten, D.L., Morris, G.S., Ramanadham, S., \& Yarasheski, K.E. (1998). Isolation of human skeletal muscle myosin heavy chain and actin for measurement of fractional synthesis rates. American Journal of Physiology, 275(6), E1092-E1099. PubMed ID: 9843753.

Hesketh, S., Srisawat, K., Sutherland, H., Jarvis, J., \& Burniston, J. (2016). On the rate of synthesis of individual proteins within and between different striated muscles of the rat. Proteomes, 4(1), 12. doi:10.3390/ proteomes4010012

Holloszy, J.O., Oscai, L.B., Don, I.J., \& Molé, P.A. (1970). Mitochondrial citric acid cycle and related enzymes: Adaptive response to exercise. Biochemical and Biophysical Research Communications, 40(6), 13681373. PubMed ID: 4327015 doi:10.1016/0006-291X(70)90017-3

Holwerda, A.M., Kouw, I.W., Trommelen, J., Halson, S.L., Wodzig, W.K., Verdijk, L.B., \& van Loon, L.J. (2016). Physical activity performed in the evening increases the overnight muscle protein synthetic response to presleep protein ingestion in older men. The Journal of Nutrition, 146(7), 1307-1314. doi:10.3945/jn.116.230086

Holwerda, A.M., Overkamp, M., Paulussen, K.J.M., Smeets, J.S.J., van Kranenburg, J., Backx, E.M.P., . . . van Loon, L.J.C. (2018a). Protein supplementation after exercise and before sleep does not further augment muscle mass and strength gains during resistance exercise training in active older men. The Journal of Nutrition, 148(11), 1723 1732. doi:10.1093/jn/nxy169

Holwerda, A.M., Paulussen, K.J.M., Overkamp, M., Smeets, J.S.J., Gijsen, A.P., Goessens, J.P.B., . . . van Loon, L.J.C. (2018b). Daily resistance-type exercise stimulates muscle protein synthesis in vivo in young men. Journal of Applied Physiology, 124(1), 66-75. doi:10. 1152/japplphysiol.00610.2017

Jaleel, A., Short, K.R., Asmann, Y.W., Klaus, K.A., Morse, D.M., Ford, G.C., \& Nair, K.S. (2008). In vivo measurement of synthesis rate of individual skeletal muscle mitochondrial proteins. American Journal of Physiology-Endocrinology and Metabolism, 295(5), E1255E1268.

Kasumov, T., Ilchenko, S., Li, L., Rachdaoui, N., Sadygov, R.G., Willard, B., . . . Previs, S. (2011). Measuring protein synthesis using metabolic ${ }^{2} \mathrm{H}$ labeling, high-resolution mass spectrometry, and an algorithm. Analytical Biochemistry, 412(1), 47-55. PubMed ID: 21256107 doi:10.1016/j.ab.2011.01.021

Katzeff, H.L., Ojamaa, K.M., \& Klein, I. (1995). The effects of long-term aerobic exercise and energy restriction on protein synthesis. Metabolism, 44(2), 188-192. PubMed ID: 7869914 doi:10.1016/00260495(95)90263-5

Kubica, N., Bolster, D.R., Farrell, P.A., Kimball, S.R., \& Jefferson, L.S. (2005). Resistance exercise increases muscle protein synthesis and translation of eukaryotic initiation factor 2Bepsilon mRNA in a mammalian target of rapamycin-dependent manner. Journal of 
Biological Chemistry, 280(9), 7570-7580. doi:10.1074/jbc. M413732200

Makatsori, A., Duncko, R., Schwendt, M., Moncek, F., Johansson, B.B., \& Jezova, D. (2003). Voluntary wheel running modulates glutamate receptor subunit gene expression and stress hormone release in Lewis rats. Psychoneuroendocrinology, 28(5), 702-714. PubMed ID: 12727136 doi:10.1016/S0306-4530(02)00062-8

Miller, B.F., Baehr, L.M., Musci, R.V., Reid, J.J., Peelor, F.F., Hamilton, K.L., \& Bodine, S.C. (2019). Muscle-specific changes in protein synthesis with aging and reloading after disuse atrophy. Journal of Cachexia, Sarcopenia and Muscle, 10(6), 1195-1209.

Moore, D.R., Tang, J.E., Burd, N.A., Rerecich, T., Tarnopolsky, M.A., \& Phillips, S.M. (2009). Differential stimulation of myofibrillar and sarcoplasmic protein synthesis with protein ingestion at rest and after resistance exercise. Journal of Physiology, 587(Pt. 4), 897-904. doi:10.1113/jphysiol.2008.164087

Mosoni, L., Valluy, M.C., Serrurier, B., Prugnaud, J., Obled, C., Guezennec, C.Y., \& Mirand, P.P. (1995). Altered response of protein synthesis to nutritional state and endurance training in old rats. American Journal of Physiology, 268(2, Pt. 1), E328-E335. PubMed ID: 7864110

Munoz, K.A., Aannestad, A., Tischler, M.E., \& Henriksen, E.J. (1994). Skeletal muscle protein content and synthesis after voluntary running and subsequent unweighting. Metabolism, 43(8), 994-999. PubMed ID: 8052157 doi:10.1016/0026-0495(94)90179-1

Murphy, C.H., Shankaran, M., Churchward-Venne, T.A., Mitchell, C.J., Kolar, N.M., Burke, L.M., . . . Phillips, S.M. (2018). Effect of resistance training and protein intake pattern on myofibrillar protein synthesis and proteome kinetics in older men in energy restriction. Journal of Physiology, 596(11), 2091-2120. doi:10.1113/JP275246

Neese, R.A., Misell, L.M., Turner, S., Chu, A., Kim, J., Cesar, D., . . . Hellerstein, M.K. (2002). Measurement in vivo of proliferation rates of slow turnover cells by ${ }^{2} \mathrm{H}_{2} \mathrm{O}$ labeling of the deoxyribose moiety of DNA. Proceedings of the National Academy of Sciences of the United States of America, 99(24), 15345-15350. PubMed ID: 12424339 doi:10.1073/pnas.232551499

Ogasawara, R., Fujita, S., Hornberger, T.A., Kitaoka, Y., Makanae, Y., Nakazato, K., \& Naokata, I. (2016). The role of mTOR signalling in the regulation of skeletal muscle mass in a rodent model of resistance exercise. Scientific Reports, 6, 31142. doi:10.1038/srep31142

Ogasawara, R., Sato, K., Matsutani, K., Nakazato, K., \& Fujita, S. (2014). The order of concurrent endurance and resistance exercise modifies mTOR signaling and protein synthesis in rat skeletal muscle. American Journal of Physiology-Endocrinology and Metabolism, 306(10), E1155-E1162. PubMed ID: 24691029 doi:10.1152/ ajpendo.00647.2013

Price, J.C., Khambatta, C.F., Li, K.W., Bruss, M.D., Shankaran, M., Dalidd, M., . . . Hellerstein, M.K. (2012). The effect of long term calorie restriction on in vivo hepatic proteostatis: A novel combination of dynamic and quantitative proteomics. Molecular \& Cellular Proteomics, 11(12), 1801-1814. PubMed ID: 22984287 doi:10.1074/ mcp.M112.021204

Qiao, Q., Bouwman, F.G., Baak, M.A.V., Renes, J., \& Mariman, E.C.M. (2019). Glucose restriction plus refeeding in vitro induce changes of the human adipocyte secretome with an impact on complement factors and cathepsins. International Journal of Molecular Sciences, 20(16), 4055. doi:10.3390/ijms20164055

Robinson, M.M., Turner, S.M., Hellerstein, M.K., Hamilton, K.L., \& Miller, B.F. (2011). Long-term synthesis rates of skeletal muscle DNA and protein are higher during aerobic training in older humans than in sedentary young subjects but are not altered by protein supplementation. The FASEB Journal, 25(9), 3240-3249. doi:10. 1096/fj.11-186437

Rooyackers, O.E., Adey, D.B., Ades, P.A., \& Nair, K.S. (1996). Effect of age on in vivo rates of mitochondrial protein synthesis in human skeletal muscle. Proceedings of the National Academy of Sciences of the United States of America, 93(26), 15364-15369. PubMed ID: 8986817 doi:10.1073/pnas.93.26.15364

Shankaran, M., King, C.L., Angel, T.E., Holmes, W.E., Li, K.W., Colangelo, M., . . . Hellerstein, M.K. (2016a). Circulating protein synthesis rates reveal skeletal muscle proteome dynamics. Journal of Clinical Investigation, 126(1), 288-302. doi:10.1172/JCI79639

Shankaran, M., Shearer, T.W., Stimpson, S.A., Turner, S.M., King, C., Wong, P.-Y., . . Evans, W.J. (2016b). Proteome-wide muscle protein fractional synthesis rates predict muscle mass gain in response to a selective androgen receptor modulator in rats. American Journal of Physiology-Endocrinology and Metabolism, 310(6), E405-E417. doi:10.1152/ajpendo.00257.2015

Sollanek, K.J., Burniston, J.G., Kavazis, A.N., Morton, A.B., Wiggs, M.P., Ahn, B., . . . Powers, S.K. (2017). Global proteome changes in the rat diaphragm induced by endurance exercise training. PLoS One, 12(1), e0171007. PubMed ID: 28135290 doi:10.1371/journal.pone.0171007

Vogel, M.A.A., Wang, P., Bouwman, F.G., Hoebers, N., Blaak, E.E., Renes, J., . . . Goossens, G.H. (2019). A comparison between the abdominal and femoral adipose tissue proteome of overweight and obese women. Scientific Reports, 9(1), 4202. PubMed ID: 30862933 doi:10.1038/s41598-019-40992-x

Wang, D., Liem, D.A., Lau, E., Ng, D.C., Bleakley, B.J., Cadeiras, M., . . . Ping, P. (2014). Characterization of human plasma proteome dynamics using deuterium oxide. Proteomics Clinical Applications, 8(7-8), 610-619.

Wang, W., Ding, Z., Solares, G.J., Choi, S.-M., Wang, B., Yoon, A., . . Ivy, J.L. (2017). Co-ingestion of carbohydrate and whey protein increases fasted rates of muscle protein synthesis immediately after resistance exercise in rats. PLoS One, 12(3), e0173809. PubMed ID: 28296942 doi:10.1371/journal.pone.0173809

Werme, M., Thorén, P., Olson, L., \& Brené, S. (1999). Addiction-prone Lewis but not Fischer rats develop compulsive running that coincides with downregulation of nerve growth factor inducible-B and neuronderived orphan receptor 1. The Journal of Neuroscience, 19(14), 6169-6174. PubMed ID: 10407052 doi:10.1523/JNEUROSCI.1914-06169.1999

Wilkinson, D.J., Franchi, M.V., Brook, M.S., Narici, M.V., Williams, J.P., Mitchell, W.K., . . . Smith, K. (2014). A validation of the application of $\mathrm{D}_{2} \mathrm{O}$ stable isotope tracer techniques for monitoring day-to-day changes in muscle protein subfraction synthesis in humans. American Journal of Physiology-Endocrinology and Metabolism, 306(5), E571-E579. PubMed ID: 24381002 doi:10.1152/ajpendo.00650.2013

Wilkinson, S.B., Phillips, S.M., Atherton, P.J., Patel, R., Yarasheski, K.E., Tarnopolsky, M.A., \& Rennie, M.J. (2008). Differential effects of resistance and endurance exercise in the fed state on signalling molecule phosphorylation and protein synthesis in human muscle. The Journal of Physiology, 586(15), 3701-3717. PubMed ID: 18556367 doi:10.1113/jphysiol.2008.153916

Wong, T.S., \& Booth, F.W. (1990). Protein metabolism in rat gastrocnemius muscle after stimulated chronic concentric exercise. Journal of Applied Physiology, 69(5), 1709-1717. doi:10.1152/jappl.1990.69.5.1709

Zangarelli, A., Chanseaume, E., Morio, B., Brugère, C., Mosoni, L., Rousset, P., . . . Walrand, S. (2006). Synergistic effects of caloric restriction with maintained protein intake on skeletal muscle performance in 21-month-old rats: A mitochondria-mediated pathway. The FASEB Journal, 20(14), 2439-2450. doi:10.1096/fj.05-4544com 